\title{
LînNTING
}

\section{SEKOLAH MODE ESMOD DI BANJARMASIN ESMOD MODE SCHOOL IN BANJARMASIN}

\author{
Mintorwati \\ Program Studi Teknik Arsitektur Fakultas Teknik Universitas Lambung Mangkurat \\ 1610812220013@mhs.ulm.ac.id
}

\author{
Irwan Yudha Hadinata \\ Program Studi Teknik Arsitektur Fakultas Teknik Universitas Lambung Mangkurat \\ irwan.yudha@ulm.ac.id
}

\begin{abstract}
ABSTRAK
Perancangan Sekolah Fashion di Banjarmasin di latar belakangi oleh pesatnya peningkatan kebutuhan fashion. Banyak potensi perancang-perancang muda di Indonesia juga menunjukkan bahwa produk fashion di Indonesia memiliki potensi yang besar. Namun, di Kalimantan Selatan khususnya kota Banjarmasin, belum mempunyai Sekolah Tinggi Fashion Design sehingga masyarakat setempat yang ingin menjadi seorang fashion designer harus menimba ilmu di luar pulau Kalimantan. Dengan adanya sekolah mode di Banjarmasin, diharapkan masyarakat Banjarmasin dan sekitarnya yang memiliki cita cita menjadi Fashion Designer ataupun ingin tahu tentang apa itu Fashion Design. Sehingga Sekolah mode fashion design di Banjarmasin dapat melahirkan designer-designer baru yang dapat menjadi pemicu industri fashion di Indonesia, khususnya di Banjarmasin. Dalam Perancangan ini, penulis menggunakan konsep Arsitektur Ekspresionisme sebagai jawaban atas permasalahan pada perancangan sekolah ini.
\end{abstract}

Kata kunci: Sekolah Fashion, Mode, Fashion, Sekolah Mode.

\section{ABSTRACT}

The Design of Fashion Schools in Banjarmasin is in the background by the rapid increase of fashion needs. Some potential young designers in Indonesia also show that fashion products in Indonesia have a great potential. However, in South Kalimantan, especially Banjarmasin, does not yet have a Fashion Design high school, it makes the local people who want to become a fashion designer must study outside the island of Kalimantan. With the existence of a fashion school in Banjarmasin, it is expected that Banjarmasin and the surrounding communities who have aspirations to become a Fashion Designer or want to know about what is Fashion Design. So, the fashion design school in Banjarmasin can give birth to new designers who can trigger the fashion industry in Indonesia, especially in Banjarmasin. In this design, the researcher uses the concept of Expressionist Architecture as an answer to the research problems in the design of this school.

Keywords: Fashion School, Mode, Fashion, Mode School. 


\section{PENDAHULUAN}

Di Indonesia, sebuah tren fashion dari berbagai macam negara dengan cepat masuk menyebar melalui internet, khususnya sosial media. Berbagai macam produk mulai bermunculan di pasar lokal, namun produk tersebut masih memiliki kualitas bahan serta pengerjaan yang kurang baik.

Jika fashion sudah menjadi bagian dari gaya hidup, kesan modern dan eksklusif akan didapatkan apabila mengikuti orientasi fashion dari luar negeri. Tetapi, bila ditingkatkan secara konsisten dengan visi misi yang kuat, budaya dengan unsur lokal di Indonesia dapat menjadi ciri khas yang baru dalam dunia fashion. SDA

Triawan Munaf selaku kepala Badan Ekonomi Kreatif (Bekraf) menyampaikan bahwa ekonomi kreatif semakin diminati serta mempunyai potensi yang baik. Pada tahun 2016, kontribusi ekonomi kreatif terhadap perekonomian di Indonesia mencapai sebesar $7,44 \%$ dan diperkirakan akan terus mengalami peningkatan (SWA, 2018). Selain itu, fashion juga berada diposisi yang lumayan tinggi, yaitu urutan kedua dalam tiga subsektor pada ekonomi kreatif dengan pendapatan tertinggi yaitu $18,15 \%$. Indonesia juga menjadi runner up sebagai negara yang berhasil mengembangkan fashion muslim terbaik di dunia setelah Arab, menurut data The State of Global Islamic Economy Report tahun 2018/ 2019 (Press Release, 2020).

Di Banjarmasin sendiri, masyarakatnya dikenal sangat konsumtif dan memiliki tingkat gengsi yang tinggi dalam hal fashion. Contohnya saja seperti toko baju wanita yang sangat menjamur di Banjarmasin, yang mana barangnya berasal dari luar pulau. Berdasarkan survei sementara yang telah dilakukan di SMK Negeri 4 Banjarmasin, SMK 1 Negeri Martapura, dan SMK Negeri 1 Pelaihari di jurusan Tata Busana, $72 \%$ siswanya mengaku ingin melanjutkan pendidikan ke jenjang yang lebih serius (Riskyana, 2020), namun di Kalimantan Selatan khususnya kota Banjarmasin, belum ada menyediakan fasilitas sekolah tinggi di bidang fashion design, sehingga banyak masyarakat di Banjarmasin yang memiliki minat fashion design harus bersekolah di luar pulau.

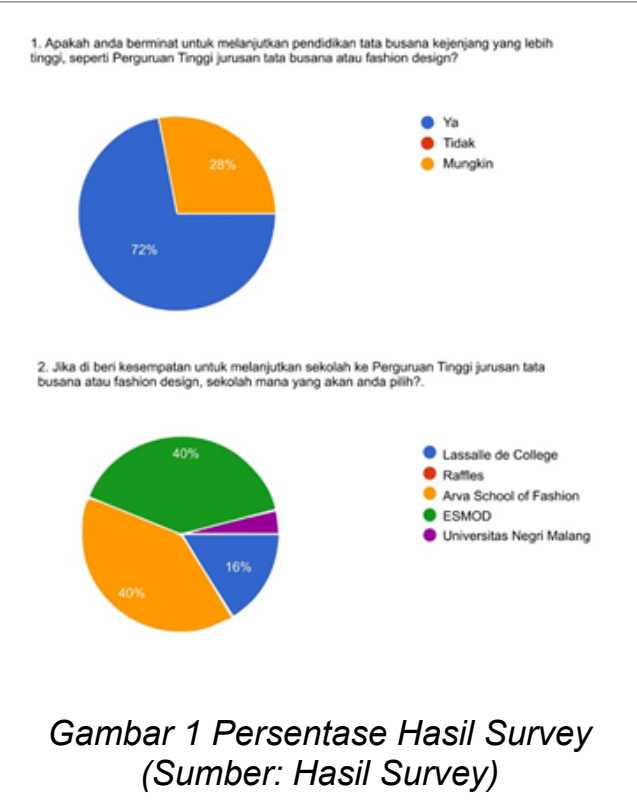

Dari data yang telah disebutkan tadi, dengan adanya sekolah tinggi fashion di Banjarmasin, nantinya masyarakat yang memiliki minat tidak perlu cemas lagi pergi jauh ke luar pulau untuk bersekolah atau mendapatkan informasi tentang fashion design, dengan diiringi cara ajar yang tersistematis, terarah, dan teknik yang berkualitas sehingga diharapkan dapat melahirkan banyak desainer muda yang mampu memicu dan memberikan karakteristik Indonesia yang khas pada fashion.

\section{PERMASALAHAN}

Setelah mengkaji latar belakang dan unsur yang mempengaruhi kondisi fashion yang ada di Indonesia khususnya Banjarmasin, maka permasalahan arsitektural yang dapat dirumuskan adalah "Bagaimana rancangan yang bisa mewadahi berbagai macam aktivitas sekolah mode 
yang ada dengan suasana yang lebih inspiratif dan bercitra fashion?"

\section{TINJAUAN PUSTAKA}

\section{A. Tinjauan Fashion}

Fashion sudah menjadi bagian dari gaya hidup. Pakaian dan aksesoris yang dikenakan tidak hanya sebagai penutup dan hiasan tubuh, namun lebih dari itu dapat menjadi alat komunikasi untuk menyampaikan identitas diri.

Upaya manusia dalam berhias agar penampilannya dapat menonjol bukanlah hal yang baru. Jauh sebelum zaman modern, upaya ini sudah lama dilakukan. Hal tersebut dapat dilihat di museum sejarah atau relief candi, dimana pada zaman tersebut pakaian dan perhiasan berasal dari kerang, manik-manik, batu alam, dan emas yang dijadikan sebagai elemen pelengkap pada penampilan seseorang.

Para produsen, berlomba untuk menghasilkan barang bukan lagi hanya sekedar fungsinya, namun bagaimana barang tersebut bisa menggambarkan kepribadian si pemakai. Persoalan gaya adalah budaya yang penting bagi masyarakat. Setiap individu diminta untuk mengontrol peran mereka sendiri mulai dari gaya pakaian, rambut, aksesoris, selera musik, atau pilihan kegiatan yang dilakukan, hal tersebut menjadi suatu bagian dari pertunjukkan identitas diri. Seseorang kemudian bisa memilih tipe kepribadian yang diinginkan, seperti bintang film, iklan, penyanyi, model, dll. Semua yang telah dijelaskan tadi bertujuan agar seseorang bisa menunjukkan siapa dirinya, karena gaya adalah segala-galanya, dan segala-galanya adalah gaya (Hendariningrum \& Susilo, 2008).

\section{B. Tinjauan Sekolah Fashion Design ESMOD}

Sekolah mode tertua di dunia adalah ESMOD, memiliki kurikulum dari Paris yang mana setiap cabangnya memiliki kurikulum yang sama. Berdiri sejak tahun 1966 di Jakarta oleh Ibu Hartini Hartanto, yang memiliki 4 program jurusan, yaitu (ESMOD Jakarta, 2020):

\section{Fashion Design \& Pattern Drafting (Program intensif 1 tahun)}

Program ini dirancang untuk siswa yang ingin menjelajahi dunia fashion dan juga mempelajari keterampilan pengerjaan nyata. Para siswa diajarkan bagaimana caranya merancang pakaian dalam struktur koleksi dan juga menyesuaikannya dengan laju perdagangan.

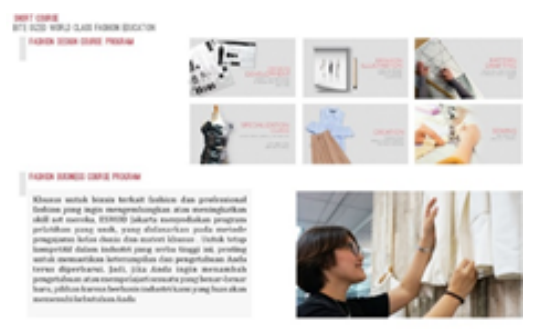

Gambar 2. Fashion Design \& Pattern Drafting Sumber: Diolah oleh penulis dari esmod.com

Ada 2 set keterampilan yang dikenal di Prancis yaitu sebagai Stylist (Fashion Design) yang melibatkan aspek desain kreatif, dan Modelisme (Pattern Drafting) yang menerjemahkan visi ke dalam sebuah konstruksi garmen melalui drafting, cutting, dan stitch. Kombinasi dari disiplin ilmu tersebutlah yang memberi metodologi ESMOD nilai tambah, serta dapat memberikan lulusan keahlian yang tak tertandingi.

Pada tahun terakhir, siswa diberikan ujian untuk dapat memvalidasi semua mata pelajaran yang telah diajarkan melalui presentasi pribadi kepada dosen. Sementara 
di Fashion Design dan Pattern Drafting, para siswa mengembangkan koleksi kapsul untuk mengekspresikan merek pribadi, dan dua penampilan akan dipresentasikan pada model pribadi dengan dosen profesional dari bidang Fashion.

\section{International Fashion Business}

(Program kuliah 3 tahun)

Program ini secara khusus disesuaikan dengan bisnis fashion, yang mengkhususkan diri dalam pemasaran, komunikasi dan distribusi di pasar desainer dan mewah. Kami telah merancang program bisnis ini untuk meningkatkan fokus pada kewirausahaan, karena pasar Indonesia saat ini menawarkan banyak sekali peluang bagi anak muda, yang bersemangat, dan kreatif. Anda akan menggunakan kemampuan Anda untuk menemukan peluang dan belajar bagaimana memasarkan ide bisnis kreatif anda.

Selama tiga tahun, siswa akan memperoleh pemahaman tentang masalah pemasaran hari ini dan mampu membayangkan masalah di masa depan dan menerapkan keterampilan yang telah mereka pelajari untuk menyelesaikannya. Mereka akan memahami realitas medan industri fashion dan peran setiap aktivitas profesional dalam pemasaran dan komunikasi. Magang akan memperkuat keterampilan yang diperoleh di kelas dengan memungkinkan siswa bereksperimen di dunia nyata.

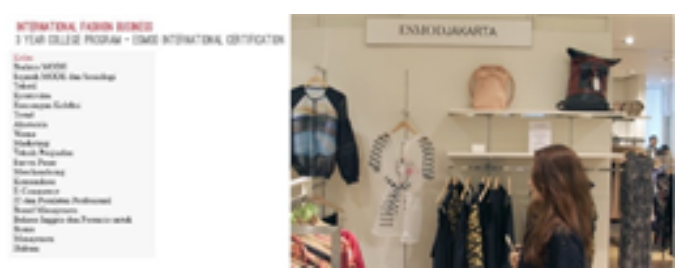

Gambar 3. International Fashion Business Sumber: Diolah oleh penulis dari esmod.com

\section{Fashion Design \& Creation (Program kuliah 3 tahun)}

\section{International Fashion Business} terbagi menjadi 2 bagian, yaitu desain dengan proses kreatif dan pembuatan pola yang berhubungan dengan konstruksi seperti melipat, menggantung, memotong, dan menjahit.
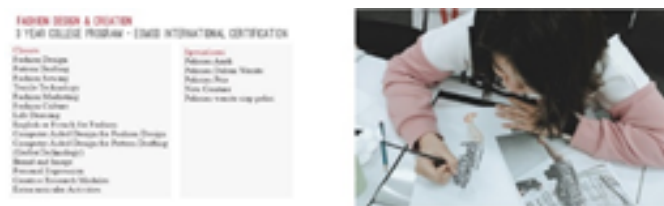

Gambar 4. Fashion Design \& Creation

Sumber: Diolah oleh penulis dari esmod.com

\section{Short Course}

Pada Short Course tujuan utamanya adalah untuk para pebisnis di bidang professional fashion yang ingin mengembangkan skillnya lebih baik lagi, dimana ESMOD Jakarta menyediakan program pelatihan yang cukup unik, yaitu berdasarkan pada metode pengajaran kelas dunia serta materi yang khusus.

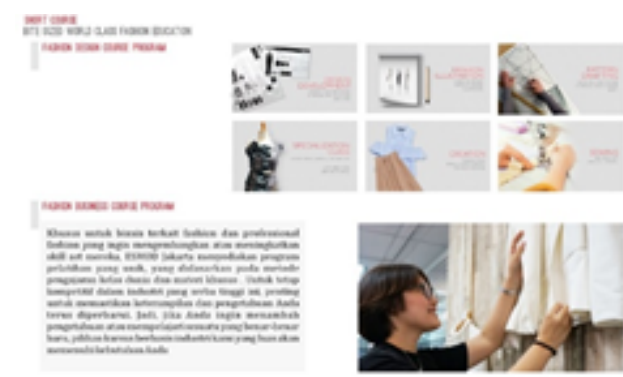

Gambar 5. Short Course

Sumber: Diolah oleh penulis dari esmod.com

\section{Tinjauan Konsep Ekspresionisme}

Ekspresionisme dalam dunia arsitektur adalah tentang pengutamaan ide perancangannya pada emosional si perancang agar bisa diterapkan. Bentuk 
ekspresi dapat berupa sebuah kemarahan, kesedihan, kegembiraan, dan emosi depresi. Ekspresionis terbagi menjadi beberapa aliran, yaitu:

1. Romantik, adalah aliran yang mengutamakan perasaan;

2. Idealisme, adalah aliran romantik namun didasari imajinasi pengarang semata;

3. Mistisme, adalah aliran yang bernafaskan ketuhanan;

4. Surealisme, adalah aliran realis yang didominasi oleh angan-angan;

5. Simbolik, adalah aliran yang banyak menggunakan lambang dan lebih terasa sebagai suatu bentuk sindiran;

6. Psikologisme, adalah aliran yang mengutamakan nuansa kejiwaan.

Bangunan dengan aliran ekspresionisme biasanya berbentuk tidak lazim, seperti penggunaan material kaca, baja, dinding beton, dan batu. Dalam arsitektur ekspresionisme terdapat nilai-nilai, yaitu tentang menghargai kebebasan bentuk dan garis, menghasilkan bentuk bangunan yang tidak monoton, mengekspresikan emosi, ungkapan hati seseorang, menjelajahi jiwa dan melukis emosi kepada orang lain. Dalam penelitiannya Erich Mendelsohn mengatakan bahwa ekspresionis menguraikan kelompok seni dinamik yang dipimpin oleh 3 macam arsitek yaitu para kaum simbolis kristalin yang menempatkan pengalaman simbolik, para analis ruang yang sadar akan arsitektur sebagai manifestasi intelektual dari ruang abstrak, dan mereka yang mencari bentuk agar memiliki prinsip material konstruktif.

\section{PEMBAHASAN}

\section{A. Konsep Program}

Berdasarkan permasalahan dari Sekolah MODE ESMOD di Banjarmasin, Bagaimana rancangan yang bisa mewadahi berbagai macam aktivitas sekolah mode yang ada dengan suasana yang lebih inspiratif dan bercitra fashion, Penulis memilih menggunakan konsep ekspresionisme untuk permasalahan tersebut, karena dalam penerapannya metode ini dapat menjawab permasalahan arsitektur yang bercitra fashion. Hal yang sangat melekat saat perayaan fashion, panggung catwalk yang menjadi pusat perhatian akan di tunjukan pada bangunan ini dan menjadi pusat perhatian di sekolah.

\section{B. Konsep Rancangan}

\section{Konsep Bentuk}

Bentukan massa dibuat melebar kesamping untuk menyesuaikan arah tapak. Bentuk dasar bangunan merupakan transformasi dari bentuk mesin jahit yang kemudian di variasikan dengan penambahan, pengurangan, pemotongan, dan mirroring. Menggunakan elemen lengkung untuk memberikan kesan fleksibel dan dinamis pada bangunan.

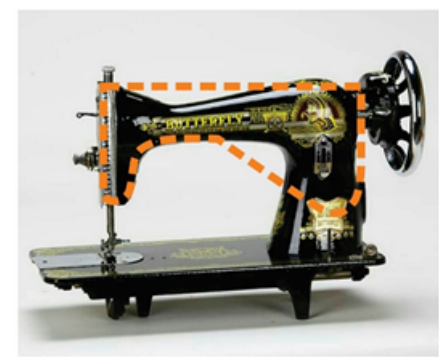

Gambar 6. Transformasi Bentuk Dasar Sumber: Analisa Penulis 


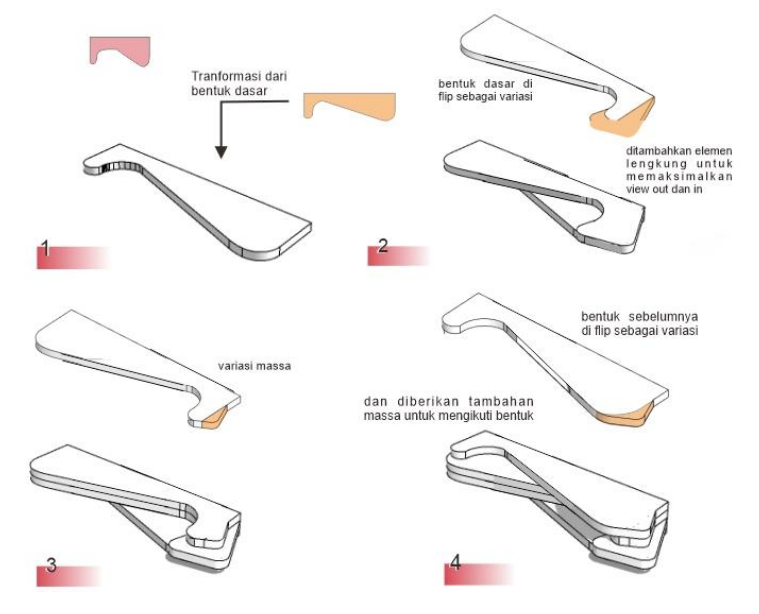

Gambar 7. Konsep Bentuk Bangunan Sumber: Analisa Penulis

\section{Konsep Ruang}

\section{a. Interaction (Interaksi)}

Menciptakan tempat komunikasi atau idea space antar pengguna bangunan yang diharapkan dapat memunculkan diskusi atau interaksi. Idea space berupa signage, spot-spot yang menarik, ataupun area dimana penggunanya dapat beristirahat ataupun bersantai yang dapat digunakan sebagai tempat untuk berdiskusi.

\section{b. Stressless Circumstance (Suasana Bebas Stress)}

Universitas ataupun sekolah merupakan tempat menimba ilmu tempat dimana dilahirkannya ide-ide kreatif, inovatif dan efek nyata dari sosial dan budaya. Akan tetapi banyak mahasiswa yang mengalami stress tingkat tinggi dalam kehidupan universitas mereka. Survei menunjukan peningkatan jumlah mahasiswa yang mengalami stress cukup signifikan, diakibatkan konflik antarpribadi, masalah harga diri, kendala keuangan, frustasi dan masalah emosional psikologisme (Mudeng \& Siswanto).

Stressless Circumstance (Suasana Bebas Stres) adalah suasana yang diharapkan dapat mengurangi pikiran negatif pengguna bangunan terutama mahasiswa.
Open space dan Nature Element dapat memberikan rasa estetika dan melibatkan lingkungan yang menarik dan menciptakan kejutan visual. Banyak ide kreatif dan inovatif yang dapat muncul, jauh dari kelas dan diskusi formal. Pemandangan alam dan suasana santai dapat mendorong pertemuan dan diskusi dadakan, serta memberikan suasana segar bagi para mahasiswa yang stress.

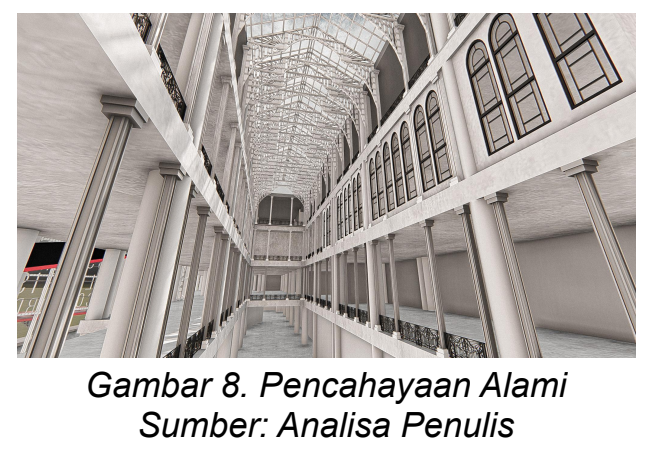

Memberikan pencahayaan alami pada kelas untuk memberikan rasa nyaman. cahaya didapat dari atap void hall yang berada di tengah hall lewat jendela. selain mendapatkan cahaya alami, siswa juga mendapatkan view yang menarik dari dalam kelas.

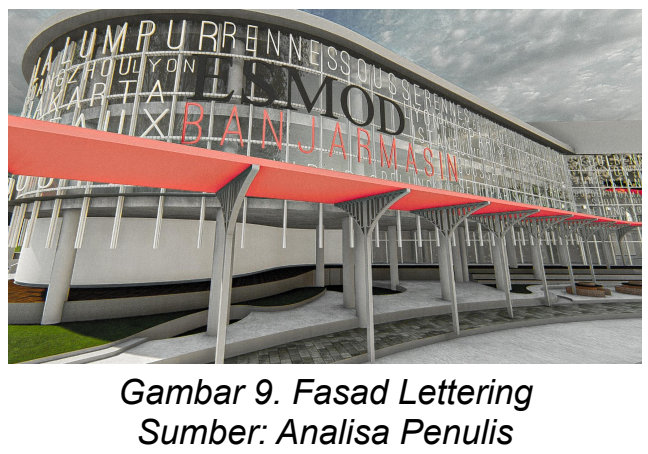

Menggunakan fasad lettering yang bertuliskan seluruh cabang ESMOD yang tersebar di seluruh dunia. memberikan kebanggan dan kepercayaan diri bagi ESMOD. Bahwa ESMOD mampu dan berusaha memberikan yang terbaik untuk dapat mengembangkan fashion di kota atau negara yang di pijaknya. 


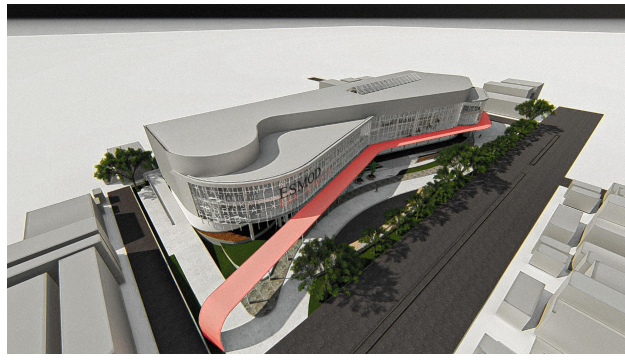

Gambar 10. Pergola Merah Sumber: Analisa Penulis

Memberikan pergola merah memanjang yang merepresentasikan catwalk dari fashion celebration sebagai identity fashion dalam wujud eksterior.
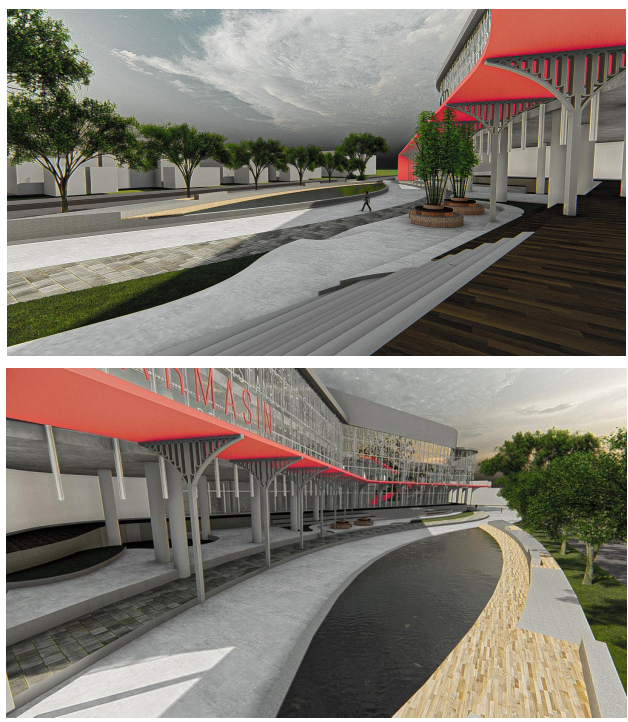

Gambar 11. Healing Garden Sumber: Analisa Penulis

Healing garden merupakan salah satu upaya stressless circumstance (suasana bebas stress) merupakan salah satu aspek yang dapat mempengaruhi terciptanya inspirasi. suasana ini diharapkan dapat mengurangi pikiran negatif pengguna bangunan terutama mahasiswa. Open space dan Nature Element dapat memberikan rasa estetika dan melibatkan lingkungan yang menarik dan menciptakan kejutan visual. Banyak ide kreatif dan inovatif yang dapat muncul, jauh dari kelas dan diskusi formal. Pemandangan alam dan suasana santai dapat mendorong pertemuan dan diskusi dadakan, serta memberikan suasana segar bagi para mahasiswa yang stress.

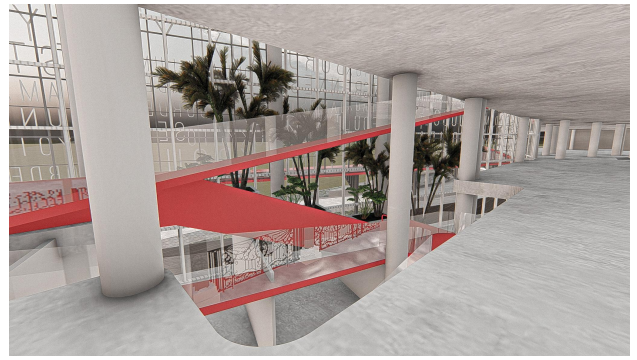

Gambar 12. Sirkulasi Ramp Sumber: Analisa Penulis

Memberikan ramp merah
memanjang yang merepresentasikan
catwalk dari fashion celebration sebagai
identity fashion dalam wujud interior.

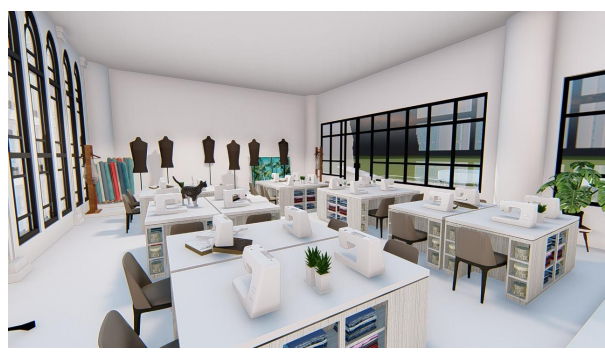

Gambar 13. Ruang Kelas

Sumber: Analisa Penulis

Menggunakan cat putih pada dinding
kelas agar mendapat suasana menenangkan dan meletakkan area kelas yang mendapat cahaya alami. memberikan vie nature element agar dapat mengurangi stress siswa dengan view tanaman di luar kelas dengan bukaan jendela yang besar maupun dengan artificial tanaman di dalam kelas. 
HASIL RANCANGAN

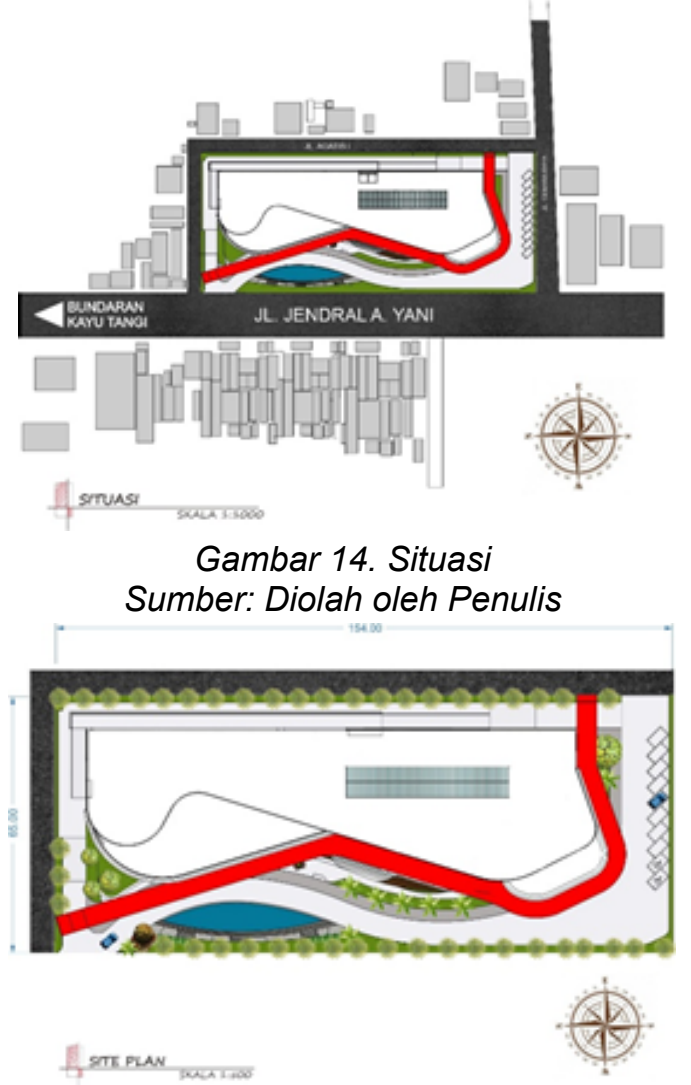

Gambar 15. Site Plan

Sumber: Diolah oleh Penulis

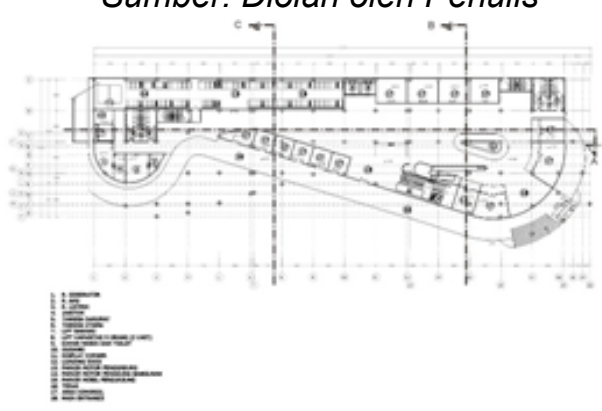

Sorverits swanes

Gambar 16. Denah Lantai 1 Sumber: Diolah oleh Penulis

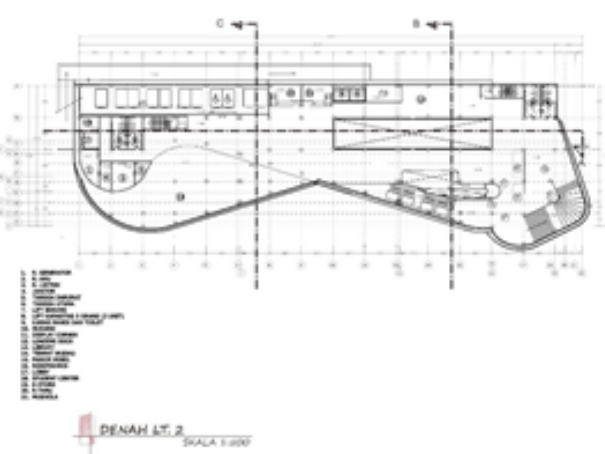

Gambar 17. Lantai 2

Sumber: Diolah oleh Penulis
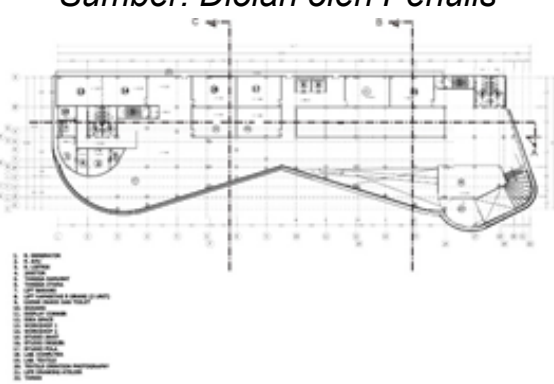

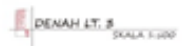

Gambar 18. Lantai 3

Sumber: Diolah oleh Penulis
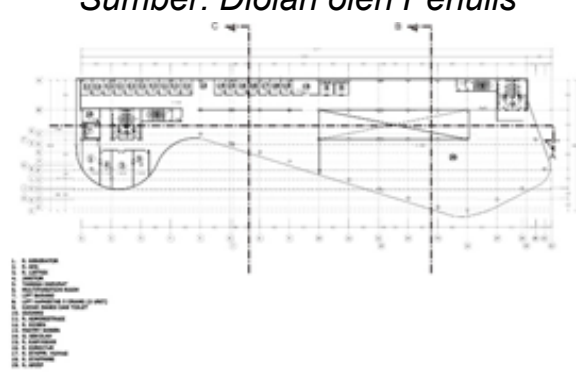

Forvantist

Gambar 19. Lantai 4 Sumber: Diolah oleh Penulis

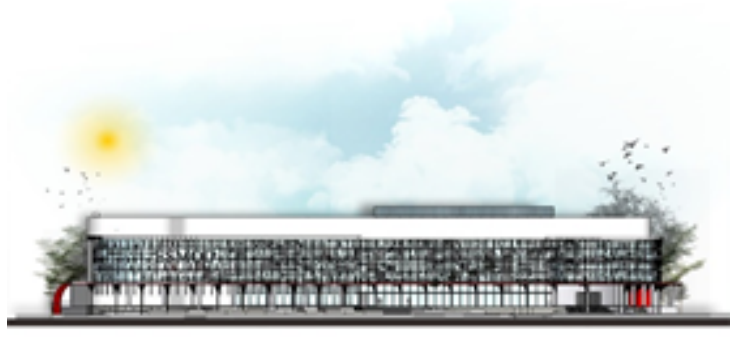

f5 TMESN DEPAN

Gambar 20. Tampak Depan

Sumber: Diolah oleh Penulis 


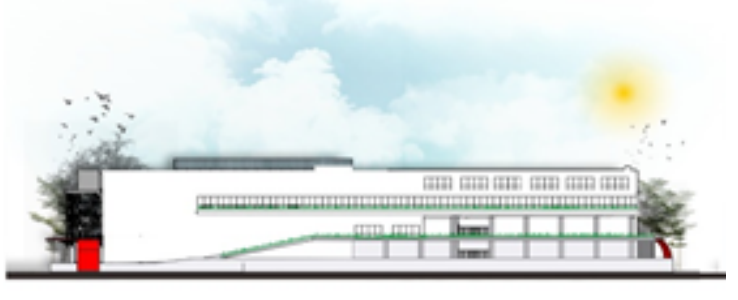

1) Tavonk betwerve

Gambar 21. Tampak Belakang

Sumber: Diolah oleh Penulis

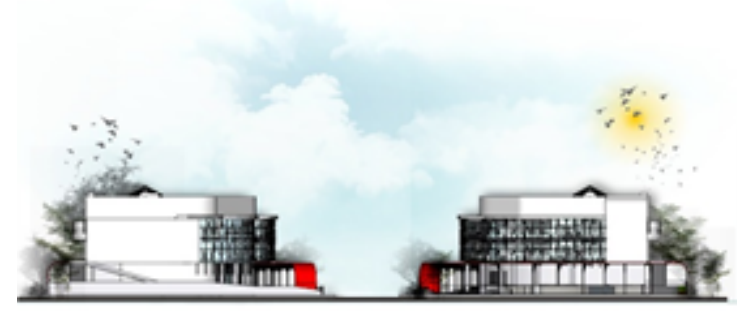

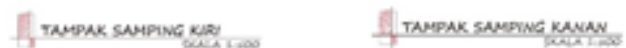

Gambar 22. Tampak Samping Kiri \& Kanan Sumber: Diolah oleh Penulis

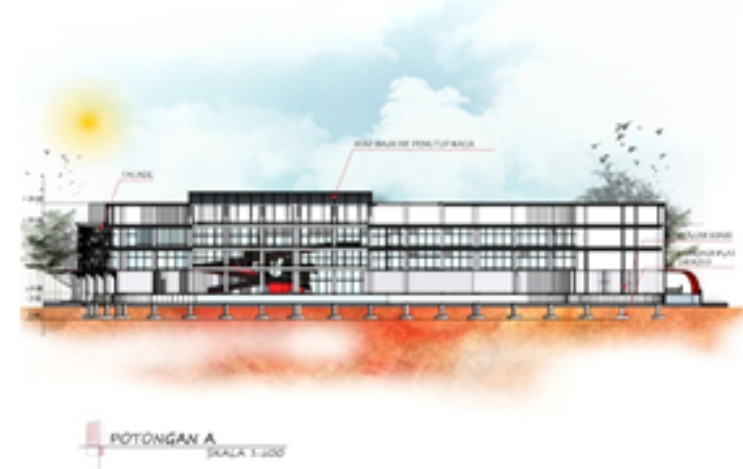

Gambar 23. Potongan A-A

Sumber: Diolah oleh Penulis

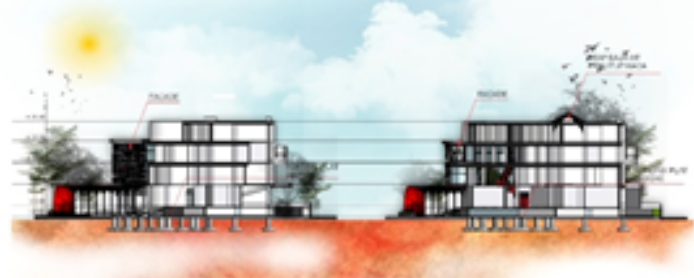

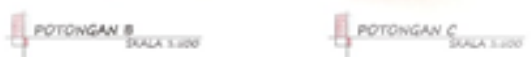

Gambar 24. Potongan B-B \& C-C Sumber: Diolah oleh Penulis
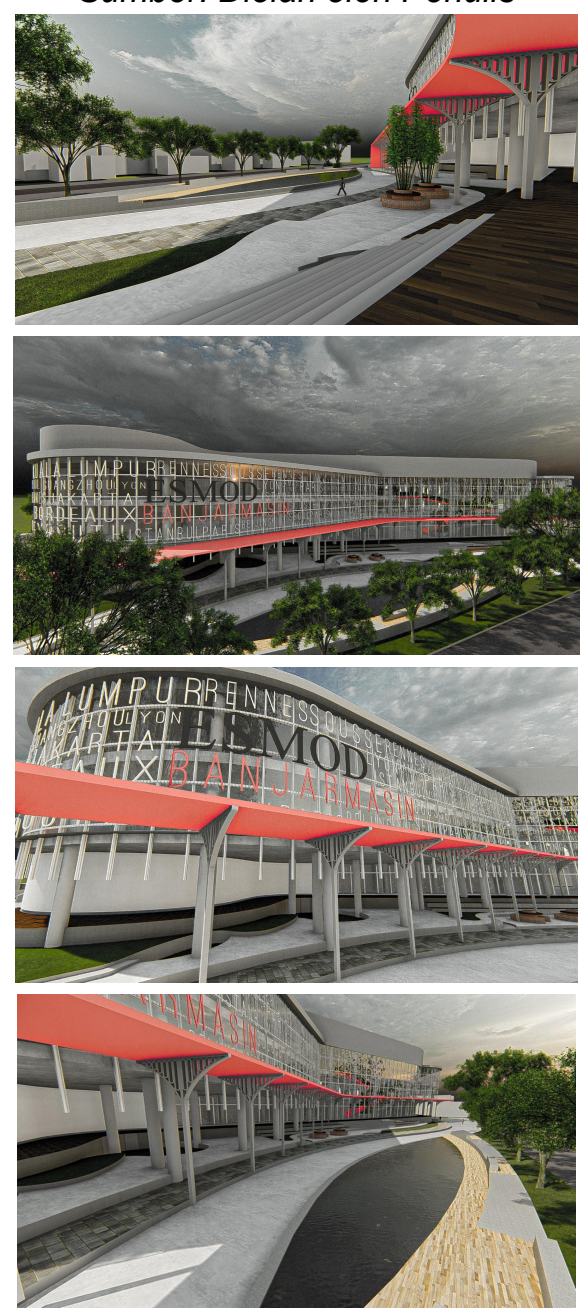

Gambar 25. Perspektif Eksterior Sumber: Diolah oleh Penulis 

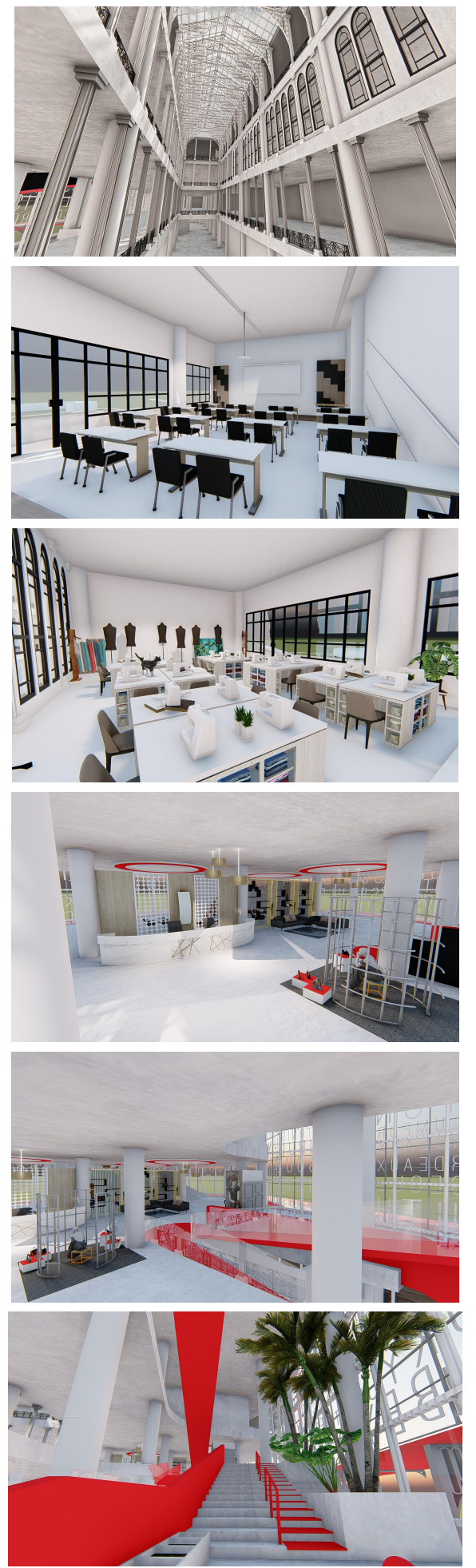
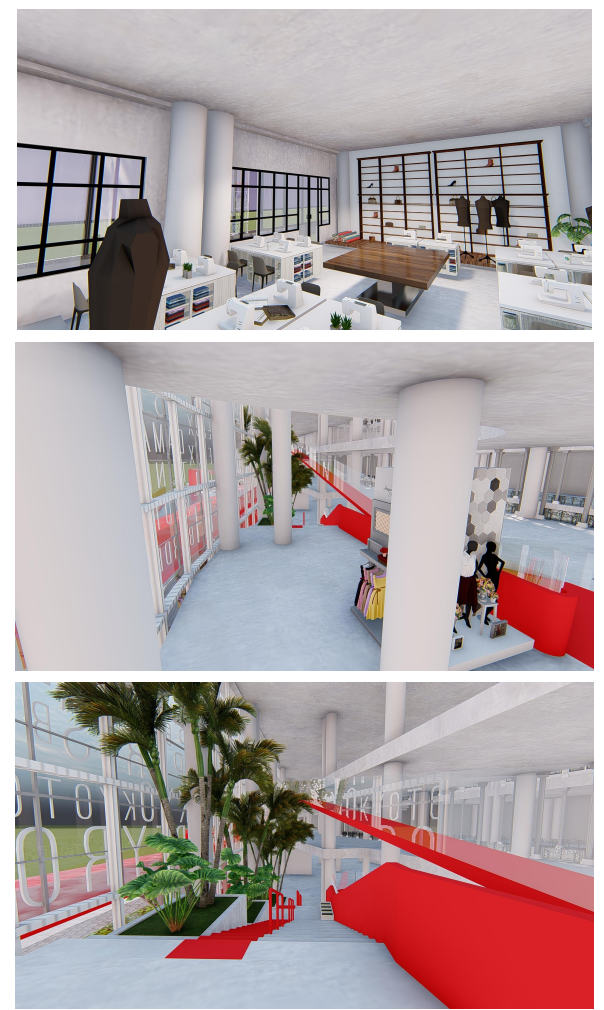

Gambar 26. Perspektif Interior

Sumber: Diolah oleh Penulis

\section{KESIMPULAN}

Sekolah Mode di Banjarmasin terletak di JI. Brigjen Hasan Basri Kec. Banjarmasin Utara Kota Banjarmasin. Site memiliki luas 9500m2 dan merupakan area pendidikan di Kota Banjarmasin yang sudah ditentukan pemerintah Kota Banjarmasin. Sekolah MODE ESMOD termasuk dalam tipe bangunan massa tunggal. Dengan fasilitas utama di dalam bangunan berupa sekolah sebagai tempat pembelajaran, dan fasilitas pendamping berupa komersial.

Perancangan Sekolah Mode di Banjarmasin bertujuan untuk mewadahi berbagai aktivitas sekolah mode yang ada dengan suasana yang inspiratif dan bercitra fashion dengan menggunakan metode ekspresionisme. Metode yang merumuskan inti dasar konsep atau DNA nya, menjadikan suatu ruang atau layout dari ruangnya menjadi ekspresi luar dari bangunan. DNA yang dipecah adalah sebagai berikut yaitu, 
mengekspos dan berekspresi. DNA mengekspos menjadi proyeksi diri dalam gaya hidup, sehingga fashion dinilai dapat mendefinisikan seseorang. DNA berekspresi menjadi penting saat semua individu merasa seperti performer, yang dapat mengontrol dan memainkan perannya masing masing.

Dengan adanya Sekolah Mode di
Banjarmasin diharapkan masyarakat Banjarmasin dan sekitarnya yang memiliki cita cita menjadi Fashion Designer ataupun ingin tahu tentang apa itu Fashion Design tidak perlu jauh-jauh lagi untuk bersekolah atau mendapatkan informasi tentang Fashion Design di luar daerah. Sehingga Sekolah mode fashion design di Banjarmasin dapat melahirkan designer-designer baru yang dapat menjadi pemicu industri fashion di Indonesia khususnya Banjarmasin.

\section{DAFTAR PUSTAKA}

\section{Referensi Buku dan Jurnal}

Hendariningrum, R., \& Susilo, M. E. (2008). Fashion dan Gaya Hidup: Identitas dan Komunikasi.

Lau, S. S., Gou, Z., \& Liu, Y. (2014). Healthy campus by open space design: Approaches and guidelines. Frontiers of Architectural Research.

Mudeng, J., \& Siswanto, W. (n.d.). Penerapan Prinsip-Prinsip Seni Ekspresionis Dalam Rancangan Arsitektur.

Permenristekdikti. (2016). Pengertian Perguruan TInggi Swasta.

Riskyana, I. (2020). Potensi Siswa Siswi di Kalimantan Selatan Terhadap Fashion Design. (Mintorwati, Interviewer)

\section{Website}

ESMOD Jakarta. (2020). Retrieved from ESMOD Jakarta: esmodjakarta.com

Press Release. (2020, September 22). Gelar MOFP, Kemenperin Angkat Potensi
Desainer Muda Bidang Fesyen Muslim. Retrieved from Press Release: https://pressrelease.kontan.co.id/release/ gelar-mofp-kemenperin-angkat-potensi-d esainer-muda-bidang-fesyen-muslim?pa ge=all

SWA. (2018, Oktober 18). Target Kontribusi Ekonomi Kreatif 2019 Untuk PDB Rp1,2 Triliun. Retrieved from swa.co.id: https://swa.co.id/swa/trends/managemen t/target-kontribusi-ekonomi-kreatif-2019-u ntuk-pdb-rp12-triliun 